\title{
Research on Ideological and Political Education of College Students under the perspective of Self- organization Theory
}

\author{
Cangjian Gao \\ School of Public Administration \\ Zhejiang Gongshang University \\ Hangzhou, China 310018
}

\author{
Cong Niu \\ School of Public Administration \\ Zhejiang Gongshang University \\ Hangzhou, China 310018
}

\begin{abstract}
In recent years, tremendous changes happen in politics, economy, culture and society at home and abroad, creating more and more complex environment for ideological and political education in universities. Self-organization theory is superior in dealing with complex problems. Problems in ideological and political education and corresponding countermeasures are proposed.
\end{abstract}

Keywords-self-organization; ideological and political; new media; values

\section{INTRODUCTION}

Each era has spirit and values of its own. [1] In recent years, with the rapid development of new media, drastic changes happen in college students' behavioral habits, expression of feelings and value orientation. On teacher-student forum of Peking University on May 4, 2014, General Secretary Xi Jinping emphasizes, "Value orientation of the young determines that of the whole society in the future. The young are at the period of forming values, so it is distinctly important to develop values in this period". [2] University students are the most representative and active group among young people, and their values can guide the whole society. Therefore, understanding university students' ideological and political characteristics has far-reaching significance on ideological and political education on them.

\section{CONCEPTS OF SELF-ORGANIZATION THEORY}

The concept of self-organization was first proposed and used by Prigogine, the founder of "dissipative structure theory" in the 1970s. [3] After clearly comparing the difference between "self-organization" and "organization", the founder of "synergetics" Haken defines "self-organization", "selforganization means a system has no external specific intervention when it obtains structures with space, time or function". The "specific" means the structure or function is not imposed by the outside world on the system. [4]

Extensive attentions are paid to self-organization theory. Scholars at home and abroad give opinions on "selforganization" in monograph and theses. The researches on selforganization theory are increasingly mature. The selforganization theory contains basic theories of dissipative structure theory, synergetics, catastrophe theory, hypercycle theory, fractal theory and chaos theory, which are independent and build frame of self-organization theory. Self-organization theory is also widely used in physics, thermodynamics, management and system science.

\section{MAIN CHARACTERISTICS OF UNIVERSITY STUDENTS'} IDEOLOGICAL AND POLITICAL EDUCATION IN THE NEW PERIOD

In recent years, the development of new media is everchanging. The widespread use of "QQ", "WeChat" and "weibo" has profoundly influenced and changed people's living habits. Rapid development of new media overturns the traditional patterns of ideological and political education. Driven by strong curiosity, university students rapidly and expertly grasp transmission mode of new media and have thoughts of their own. The widespread popularity of "BBS", "weibo" and "QQ group" and "WeChat group" as well as WeChat Official Account indicates university students' information transmission model is increasingly flexible, convenient and efficient. University students' ideological and political education in the new period has the following characteristics:

\section{A. Opener}

Open system is the premise of self-organization theory. Under open and unbalanced state, system exchanges material, energy and information with the outside world and becomes ordered. With continuous social and economic reform, the marketization degree is increasingly high. The arrival of mobile internet era makes information obtained by university students doubled and redoubled. It includes positive and negative information. University students' values are more diversified. Compared with traditional ideological and political education, the environment at present is opener and more complex.

\section{B. Decentralized}

In the traditional ideological and political education, school and teachers occupy central and dominant position because they take the initiative in grasping information transmission. The asymmetric information makes students under control. Therefore, "duck-stuffing" type of teaching can achieve the 
expected effect. The rapid development of new media overturns the traditional pattern of ideological and political education. The strong curiosity of university students makes them rapidly and expertly grasp transmission mode of new media and gradually predominate in information spreading, such as weibo and WeChat Official Account established by associations and classes spontaneously. The original information dissemination center is disappearing. Positions of school, teacher and student in ideological and political education are reconstructed. Unbalanced state will appear for a long time in the open environment.

\section{Nonlinear}

In the traditional ideological and political education, school and teachers positively guide students to establish scientific outlook on life, world outlook and values. The original ideological and political education pattern is broken and the way of information spreading is reconstructed, contributing to increasingly complex ideological and political education system. In the open external environment, external information swarms into campus. The effects of ideological and political education differ because university students obtain different information. Ideological and political education is not a complicated process that can be described by linear equation and can accurately predict the outcome but showing non-linear characteristics.

Because university students' ideological and political education in the new period is open, decentralized and nonlinear and conforms to the characteristics required by selforganization, it is a self-organization system with gradual development.

\section{PROBLEMS IN UNIVERSITY STUdENTS' IDEOLOGICAL AND POLITICAL EDUCATION}

\section{A. The Traditional Ideological and Political Education Pattern Is Impacted}

Competition promotes the development of things and the evolution of system. In ideological and political education, university, teacher and student form a system with self evolution and competitive relationship. Schools and teachers strengthen their leading role; students take advantages of thirst for knowledge and learning ability as well as new media with rapid development to seize fields such as emerging cyberspace, informal student organization and the neglected dormitory space, trying to establish equal and new ideological and political education. The traditional ideological and political education suffers from unprecedented impact. The original absolute speaking right, dominant right and initiative are disappearing.

\section{B. The Traditional Ideological and Political Education System Is Too Simple}

In the traditional ideological and political education, schools and teachers are in central position and grasp absolute initiative. Teachers teach knowledge in the classroom and teaching materials have little change for years. The ideological and political education is compulsory and hierarchical. With drastic changes of society, politics, economy and culture, the environment of ideological and political education is opener. The original system cannot meet requirements of ideological and political education even restricts its development.

\section{Abilities of Ideological and Political Educators Are Uneven}

Ideological and political education centers on teachers and students. Teacher group mainly includes teachers of ideological and political class and university counselors. Teachers of ideological and political class receive professional education, but with the ever-changing social environment, teachers and teaching materials are divorced from students' real life and become less attractive even insipid. University counselors are young and have little life experience, insufficient theoretical attainment and weak vocational ability. Different abilities of individuals make the ability of ideological and political educators differ.

\section{Ideological and Political Education on the Internet Has Absence of Supervision}

With soaring development of mobile internet in recent years, ideological and political education becomes open, decentralized and nonlinear. At the meantime, the development of new media is amazing. The convenient and efficient mobile intelligent devices make the number of internet user increase sharply. Network becomes main field for university students to exchange thoughts. However, because the original ideological and political work system has rigid response and slow response speed, the ideological and political education appears absence of supervision. The unstable events of university students in the network field happen occasionally.

\section{E. Application of Self-Organization Theory in Improving University Students' Ideological and Political Education}

1) Follow the rule of ideological and political education and go with the tide of historical development.

In self-organization theory, open system is the premise for system to exchange material, energy and information with the outside world and the source to stay active. Ideological and political education should keep open and conform to the objective development law of ideological and political education. The ideological and political education must keep abreast with the times and follow the rule of students' physical and mental growth and change the closed management mode. Meanwhile, it should go with the tide of historical development and change the traditional management style and adopt decentralized control.

2) Give play to the leading role of socialist core values.

The formation of ordered system realizes through interaction between chaotic subsystems. However, if the system forms order parameter, the development of subsystems will be controlled by it. In self-organization system, the subsystem under control is intangible and influential. In ideological and political education, we must adhere to Marxist thought and the leading role of socialist core values and form scientific and healthy order parameter, so that it will drive students to participate and help them to establish correct values. 
3) Improve comprehensive abilities of ideological and political educators to meet challenges in the new period.

Ideological and political education cannot do without ideological and political educators. First, team including cadres of party and government, communist youth league cadre, teachers of ideological and political theory course, teachers of philosophy and social sciences, school psychologist, class teacher and counselors must be constructed. Theoretical attainment and problem-solving abilities of them should be improved; on the other hand, improve ability of ideological and political educators in continuous learning. With rapid development of new media, ideological and political educators who grasp and use network new media expertly to strengthen the supervision of ideological and political position on the network; strengthen the professional and vocational development of counselors and improve their professional and occupational abilities and comprehensive management capability.

4) Optimize discourse system of ideological and political course and innovate in patterns of ideological and political class.

Ideological and political education in universities aims at university students and carries out through understanding university students and ways popular among them. First, transform discourse system. Ideological and political discourse should relate to students and their life; teach through forms popular among students and interesting language and make the best of classroom teaching; innovate in pattern of ideological and political class, use emerging network teaching pattern, excavate character stories with positive energy and establish video database and online class of "ideological and political micro course", in order to carry out ideological and political education.

5) Let student organizations drive ideological and political education.

The "hypercycle" integration in self-organization theory thinks establishing hypercycle relation between different things and systems can connect things with little relation, carries out cyclic utilization of material, energy and information flow to expand space. Student organizations can play a positive role in ideological and political education. Strengthen education and guidance of leaders in student organizations and let them establish socialist core values. Meanwhile, student organizations including the Communist Youth League, student union and student club have guidance effects on ideological and political education.

\section{CONCLUSION}

Special attentions have always been paid to ideological and political education. With increasingly complex international and domestic environment, the ideological and political education has extremely special meaning. On the ideological and political working conference held on December 7 and 8, 2016 in Beijing, General Secretary Xi Jinping emphasizes ideological and political work concerns the essential issues of training what kind of people, how to train people and train people for whom, upgrading it to a higher position. [5] According to characteristics and problems of ideological and political education, countermeasures are proposed from different theoretical viewpoints to optimize structure of ideological and political education, improve comprehensive ability of ideological and political educators and let student organizations play a role in ideological and political work, in order to strengthen the innovative development of ideological and political education.

\section{REFERENCES}

[1] Xi Jinping Investigates in Peking University: Young People Must $\begin{array}{lll}\text { Practice Socialist Core Values [EB/OL], } & \text {, }\end{array}$ http://news.xinhuanet.com/politics/2014-05/04/c_126460590.htm.

[2] Xi Jinping's Speech on Teacher-student Forum in Peking University [N], People's Daily, May 5, 2015

[3] Nicolis G.Prigogine I.Self-organization in non-equilibrium system,from dissipative structures to order through fluctuations.New York Wiley, 1997.60.

[4] Haken H.Information and Self-organization A Macroscopic Approach to Complex Systems.Berlin \& New York:Springer-Verlag, Nov.1988

[5] Xi Jinping Emphasizes on Ideological and Political Working Conference: Let Ideological and Political Education Run through the Teaching Process, Create a New Situation for Development of Higher Education, [EB/OL],

http://www.moe.edu.cn/jyb_xwfb/s6052/moe_838/201612/t20161208_2 91306.html. 